\title{
SIMULATION OF INDOOR OZONE CONCENTRATION
}

\author{
S. Byčenkienė ${ }^{\mathrm{a}}$, V. Valuntaité ${ }^{\mathrm{b}}$, and R. Girgždiené $\dot{e}^{\mathrm{a}, \mathrm{b}}$ \\ ${ }^{a}$ Institute of Physics, Savanoriu 231, LT-02300 Vilnius, Lithuania \\ E-mail: bycenkiene@ar.fi.lt \\ ${ }^{\mathrm{b}}$ Vilnius Gediminas Technical University, Saulètekio 11, LT-10223 Vilnius, Lithuania
}

Received 26 March 2009; revised 27 May 2009; accepted 18 June 2009

\begin{abstract}
This paper presents a set of data obtained in experimental and theoretical studies of the indoor ozone concentration with displacement of the ozone source. The measurements were conducted for three typical room configurations. The simulation takes into account actual room sizes and deposition rates on the surface material to predict the indoor ozone concentration. Both experimental and simulated results suggest that the air exchange rate and the material surface in the room play a significant role in determining ozone levels in indoor environments. The simulated indoor ozone concentration was compared with experimental results (correlation $r=0.8$ ), and the accuracy of the model was tested.
\end{abstract}

Keywords: indoor air, ozone, concentration, modelling

PACS: $92.60 . \mathrm{Sz}, 91.10 . \mathrm{Vr}$

\section{Introduction}

Concern for the air quality of indoor air in respect of pollutants has been rising in recent years. People spend the largest part of their time indoors and as a result, the indoor concentration of pollutants can significantly influence their health. Modelling of indoor air quality is commonly used to improve the understanding of processes that affect indoor pollutant concentrations and to predict indoor pollution under different conditions. Level of pollutants in premises partly depends on characteristics of the underlying surface on which deposition of pollutants from air occurs. It is determined that the deposition rate of ozone on 16 different surfaces in premises varies over a wide range $[1,2]$. The indoor ozone concentration is usually lower compared to outdoors. The ratio of these concentrations may depend on a number of factors such as air infiltration or air exchange between indoors and outdoors, circulation of air in the room, type and structure of room surfaces, ozone reaction with other chemical compounds, etc. [3-5]. The outdoor ozone concentration has strong diurnal variations, while the indoor ozone concentration can vary significantly from hour to hour, day to day, and season to season, as well as from room to room. Under normal conditions, the half-life of ozone indoors varies usually between 7 and $10 \mathrm{~min}$ and is determined primarily by the removal rates on the surfaces and air exchange [6]. Indoor ozone and its oxidation products may be po- tentially damaging both to the human health and materials, therefore the exact prediction and simulation on other indoor pollutant concentration are needed for design of buildings $[7,8]$.

It is determined that the ratio of the ozone concentration indoors/outdoors varies from 0.10 to 0.80 [9]. Homogeneous reactions of ozone with other chemical compounds may result in formation of compounds more dangerous to the human health than ozone [10, 11]. According to the Lithuanian hygiene standard $\mathrm{HN}$ 35:2002, the marginal concentration of ozone in the workplace is $200 \mu \mathrm{g} / \mathrm{m}^{3}$, given as an average value of eight hours.

The aim of this study was to examine experimentally and theoretically the ozone concentration changes in the multi-room premises with the ozone source under different air mixing conditions between the rooms.

\section{Methodology}

The simulation of the indoor ozone concentration dynamics in a building was performed using the RISK model algorithm [12]. The experiment was carried out in the working premises to investigate the indoor ozone concentration variation taking into account an air flow and a displacement of the ozone source. In the simulation scenario the premises are treated as a set of three chambers (rooms), with specific air flow rates from each 


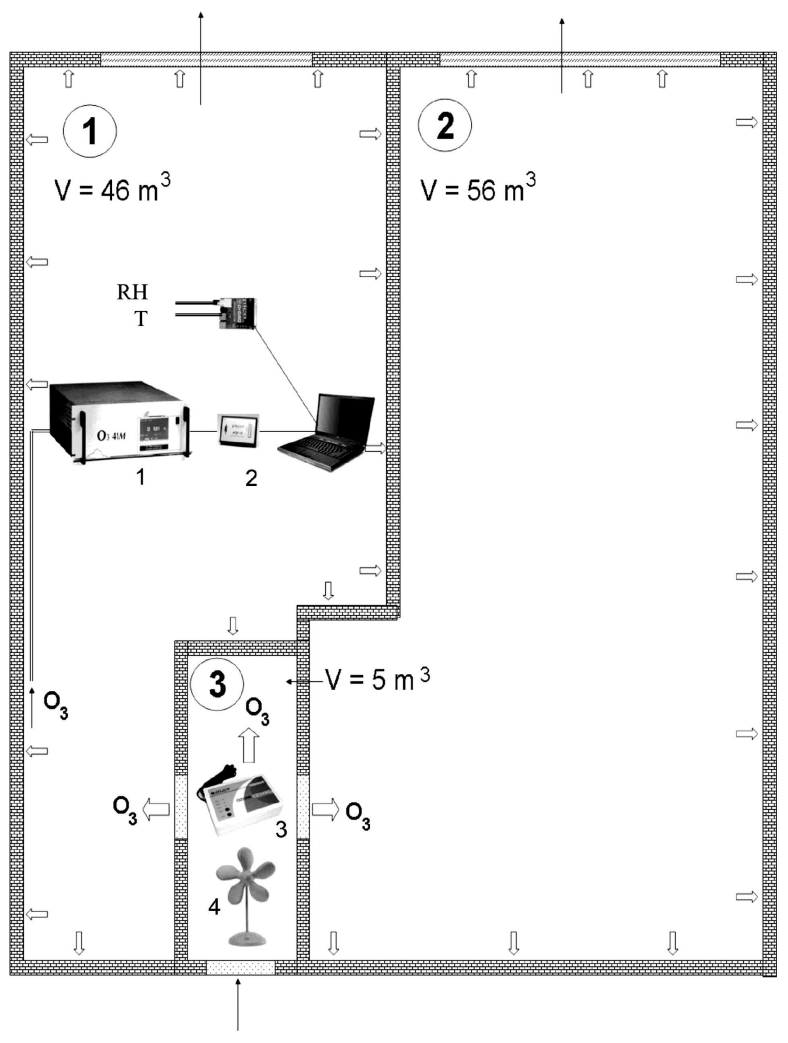

Fig. 1. Scheme for measuring the ozone concentration when ozone is generated in room 3 ( 1 ozone analyzer, 2 data logger ADC 16, 3 ozone generator, 4 ventilator).

room to all other rooms defined as a function of time (Fig. 1). The model algorithm has been used to simulate concentrations of reactive gaseous pollutant (ozone) in microenvironment as a function of air exchange rates with other microenvironments, its removal rate, as well as the ozone emission rate within the microenvironment.

Ozone was generated by the generator OZX-B300T with the ozone production of $200 \mathrm{mg} / \mathrm{h}$. The ozone concentration was measured with the ozone analyzer $\mathrm{O}_{3} 41 \mathrm{M}$, based on ultraviolet absorption. Limits of the measurements with the ozone analyzer were $0-2000 \mu \mathrm{g} / \mathrm{m}^{3}$ and sensitivity was $1 \mu \mathrm{g} / \mathrm{m}^{3}$. The ozone generator was switched on either for 10 or 30 minutes. To accelerate mixing of air, the ventilator was used. The ozone concentration, microclimate, and other parameters in the room were measured continuously by averaging data of $1 \mathrm{~min}$ in order to detect alterations of ozone emission and sinking on the surfaces. Three simulation scenarios were undertaken to examine the response of ozone data to changes both in air flow and location of the ozone source.

The model takes into account the effect of air mixing, pollutant emission, and the deposition rate on different surfaces, etc. For each room, the air mixing conditions were described. In the model, the air exchange with the outdoor air was assumed to be $0.5 \mathrm{ACH}$ (Air Changes per Hour). In the premises the air exchange rate from rooms 1 and 2 was determined to be $100 \mathrm{~m}^{3} / \mathrm{h}$ and from room 3 to other rooms $10 \mathrm{~m}^{3} / \mathrm{h}$. The stability of microclimate was ensured by limiting the changes in temperature and relative humidity. The microclimate parameters, i.e. the relative humidity $(36 \pm 2 \%)$ and temperature $\left(20 \pm 1^{\circ} \mathrm{C}\right)$, in all environments were established during the experiment. During the measurement campaign, permanent occupants were absent in the rooms. Indoor activities were registered to examine their effects on the indoor concentration.

Within each room, the rate of change of the ozone mass concentration was given by the empiric model based on the mass transfer theory. The calculation of the ozone concentration was based on source emission rates, room-to-room air movement, air exchange, and indoor sink behaviour. Air in each room $i$ was considered to be well-mixed. A mass balance for each room gives

$$
V_{i} \frac{\mathrm{d} C_{i}}{\mathrm{~d} t}=C_{i \mathrm{IN}} Q_{i \mathrm{IN}}-C_{i \text { OUT }} Q_{i \text { OUT }}+A_{i}-R_{i} .
$$

Here $V_{i}$ is the volume of the room, $C_{i}$ is the ozone concentration in the room, $C_{i \mathrm{IN}}$ is the concentration of ozone in air coming into the room, $Q_{i \mathrm{IN}}$ is the air flow into the room, $C_{i}$ OUT is the ozone concentration in air leaving the room, $Q_{i}$ OUT is the air flow leaving the room, $A_{i}$ is the ozone formation rate from the source, $R_{i}$ is the overall ozone removal rate, and $i$ refers to the room in a set of multiple rooms, $i=1,2, \ldots N$, where $N$ is the total number of rooms.

From the well-mixed assumption $\left(C_{\text {OUT }}=C_{i}\right)$ Eq. (1) can be rewritten as

$$
V_{i} \frac{\mathrm{d} C_{i}}{\mathrm{~d} t}=C_{i \mathrm{IN}} Q_{i \mathrm{IN}}-C_{i} Q_{i} \text { OUT }+A_{i}-R_{i} .
$$

The ozone concentration decrease depends on the type of surface and on indoor microclimate parameters such as temperature, humidity. The sinks (i. e., surfaces that remove pollutants from indoor air) play a major role in determining indoor ozone concentrations. The sinking model used in the RISK model is based on the research carried out by Tichenor et al. [13]:

$$
R_{i}=v_{g} C S_{\text {sink }}-v_{d} M_{g} S_{\text {sink }} .
$$

Here $v_{g}$ is the deposition rate (mass per unit time), $C$ is the ozone concentration (mass per length cubed), $S_{\text {sink }}$ is the area of the sink (length squared), $v_{d}$ is the reemission or desorption rate, $M_{g}$ is the mass collected in the sink per unit area (mass per length squared). Ozone 
Table 1. Ozone half-life $\tau$ and deposition rate $v_{g}$ on surfaces [14].

\begin{tabular}{lcc}
\hline \multicolumn{1}{c}{ Material } & $\tau, \mathrm{s}$ & $v_{g}, \mathrm{~cm} / \mathrm{s}$ \\
\hline Glass & 7620 & $1.1 \cdot 10^{-4}$ \\
Wood-wool plate & 660 & $1.2 \cdot 10^{-3}$ \\
Plastic & 5040 & $2.3 \cdot 10^{-3}$ \\
Carton & 4980 & $2.6 \cdot 10^{-3}$ \\
Polyethylene & 4740 & $3.9 \cdot 10^{-3}$ \\
Red bricks & 4560 & $4.9 \cdot 10^{-3}$ \\
Gypsum plate & 4260 & $6.8 \cdot 10^{-3}$ \\
Ceiling plate & 2280 & $3.2 \cdot 10^{-2}$ \\
Fir planks & 1680 & $5.2 \cdot 10^{-2}$ \\
Carpeting & 1680 & $5.2 \cdot 10^{-2}$ \\
Wallpaper & 1200 & $8.2 \cdot 10^{-2}$ \\
\hline
\end{tabular}

sinks are irreversible, therefore the value of the last member of Eq. (3) that describes desorption is considered negligible.

The ozone half-life $\tau$ and deposition rates $v_{g}$ on various materials of underlying surfaces of the rooms were evaluated experimentally in a chamber and estimated values were used in the simulation algorithm (Table 1).

The lowest ozone deposition rate was determined on glass $\left(1.1 \cdot 10^{-4} \mathrm{~cm} / \mathrm{s}\right)$. The obtained data show that wallpaper and carpeting are materials inducing the largest decay of ozone. Therefore, in order to reduce a possible ozone impact on the human health it is recommended to use these materials in premises where technological processes allow it.

\section{Results}

The model has been checked by comparing results of the simulation with experimental data. The data of the comparison between the measured and simulated ozone concentrations with the ozone source operating for $30 \mathrm{~min}$ in room 3 are presented in Fig. 2. It can be seen from the figure that the maximum ozone concentration of $340 \mu \mathrm{g} / \mathrm{m}^{3}$ is reached in the room with the ozone generation, whereas the highest concentrations in rooms 1 and 2 (of 190 and $170 \mu \mathrm{g} / \mathrm{m}^{3}$, respectively) are reached only in $55 \mathrm{~min}$ from the beginning of ozone generation. The highest ozone concentrations in neighbouring rooms (1 and 2) are lower compared to those in room 3 by a factor of about 1.9.

Statistically significant correlation $(r=0.8, r=$ 0.9 ) was found between the measured and simulated data in room 1 and room 3, respectively. A certain disagreement between the experimental and simulated data could be caused by the fact that the ozone deposition rate on some surfaces in the microenvironment was not included in simulation. The ozone concentration in rooms reached the maximum values later compared to the well-mixed air rooms, i. e. the lag of the ozone concentration peak was influenced by air mixing. Nevertheless, the value of the ozone concentration in rooms 1 and 2 still remained relatively high (140 and $120 \mu \mathrm{g} / \mathrm{m}^{3}$, respectively).

The ozone concentration variation in rooms when the ozone generation in room 1 was maintained for $30 \mathrm{~min}$ is shown in Fig. 3.

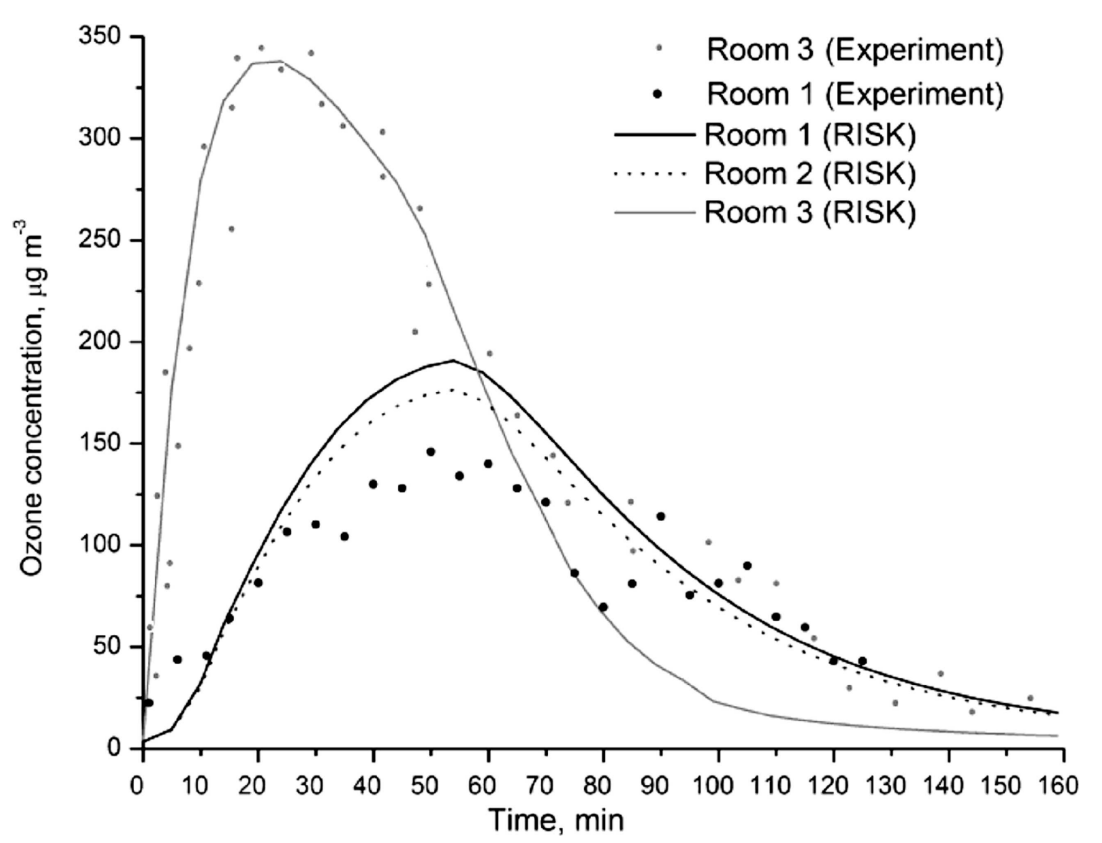

Fig. 2. Simulated and measured ozone concentrations (ozone source is located in room 3). 


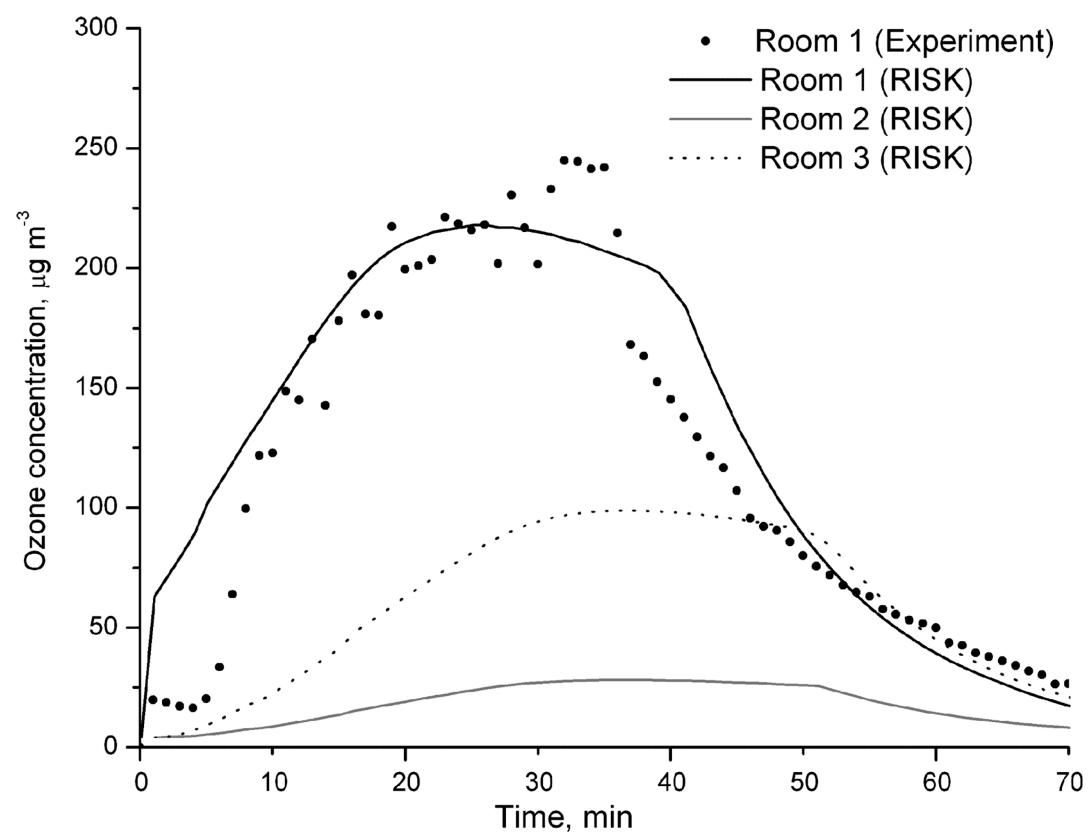

Fig. 3. Simulated and measured ozone concentrations (ozone source is located in room 1, ozone generation time 30 min).

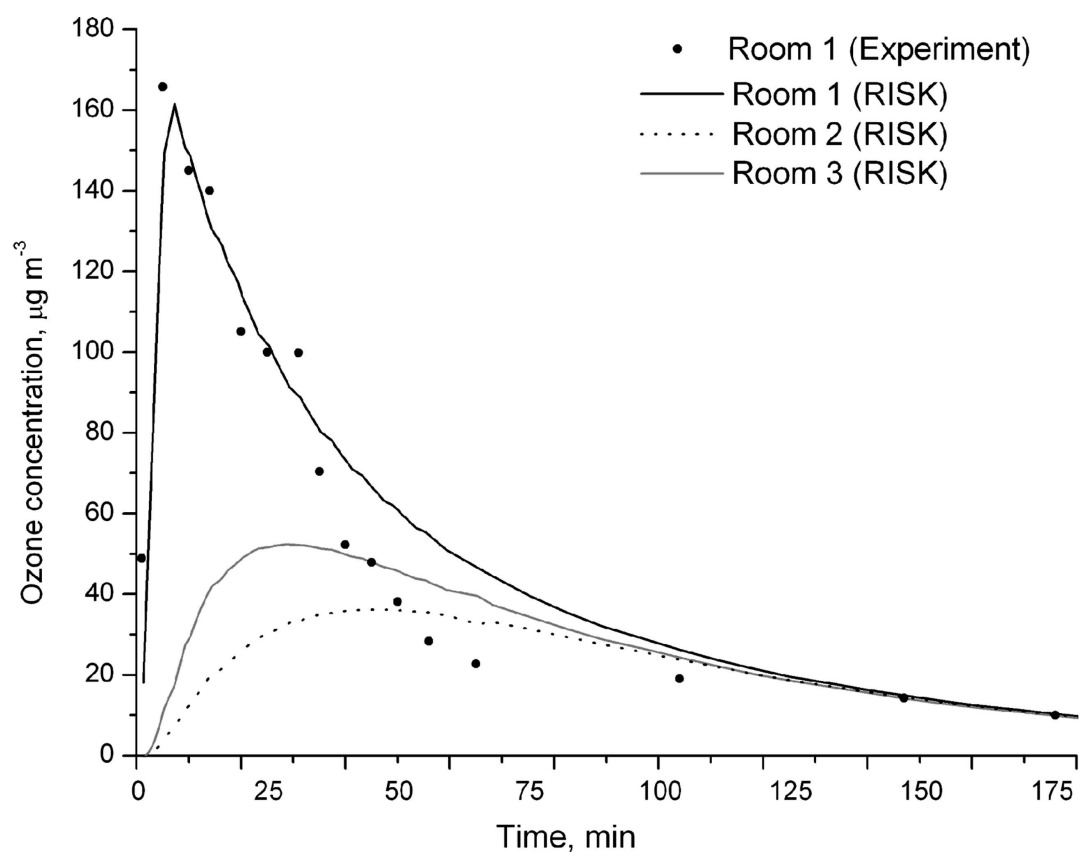

Fig. 4. Variation of simulated and measured ozone concentrations (ozone source is located in room 1, ozone generation time 10 min).

As seen from Fig. 3, good agreement between simulated and measured ozone levels in room 1 has been obtained at the beginning of the experiment $(t \leq 30 \mathrm{~min})$. However, later (with $t$ increasing up to $\sim 50 \mathrm{~min}$ ) the performed simulation gave enhanced ozone concentration values and higher rates of the ozone concentration decrease compared to the experimental data.

Figure 4 shows the experimental and simulated ozone concentration in room 1 with the ozone source located in room 1 and ozone being generated for $10 \mathrm{~min}$. The simulated ozone concentrations in rooms 2 and 3 are displayed in the same figure for comparison.

As shown in Fig. 4, the ozone concentration peak in room 1 caused by the ozone emission source operating in the same room is rather narrow, whereas similar peaks of ozone concentration curves in rooms 2 and 3 are relatively flat. The simulated values are in good agreement $(r=0.8$ ) with the experimental data of room 1 at the beginning of the experiment $(t \leq 30 \mathrm{~min})$, while later $(t>30 \mathrm{~min})$ the performed simulation has given 
enhanced concentration values and lower rates of the ozone concentration decrease compared to the experimental data.

\section{Conclusions}

The RISK model can be used to estimate the ozone level in the multi-room premises when the emission rate, ozone deposition rates on existing surfaces, and airflow data are available. In this study we considered experimental values of deposition rates, the role of air mixing and presence of an indoor ozone source emitting (10 to $30 \mathrm{~min}$ ) $200 \mathrm{mg} / \mathrm{h}$ of ozone in the simulation. The analysis of data shows that the ozone concentration is higher in the case with good air mixing in rooms. Significant correlation $(r=0.8)$ between simulated and experimental results has been obtained.

\section{References}

[1] J.G. Klenø, P.A. Clausen, C.J. Weschler, and P. Wolkoff, Determination of ozone removal rates by selected building products using the FLEC emission cell, Environ. Sci. Technol. 35(12), 2548-2553 (2001).

[2] D.J. Sutton, K.M. Nodolf, and K.K. Makino, Predicting ozone concentrations in residential structures, ASHRAE J. 19(9), 21-26 (1976).

[3] C.J. Weschler, Ozone in indoor environments: Concentration and chemistry, Indoor Air 10(4), 269-288 (2000).

[4] T. Grøntoft, Measurements and modeling of the ozone deposition velocity to concrete tiles, including the effect of diffusion, Atmos. Environ. 38(1), 49-58 (2004).
[5] S. C Lee, Sanches Lam, and Ho Kin Fai, Characterization of VOCs, ozone, and $\mathrm{PM}_{10}$ emissions from office equipment in an environmental chamber, Build. Environ. 36(7), 837-842 (2001).

[6] V. Valuntaitė and R. Girgždienè, Investigation of ozone emission and dispersion from photocopying machines, J. Environ. Eng. Landsc. Manag. XV(2), 61-67 (2007).

[7] K. Lee, J. Vallarino, T. Dumyahn, H. Özkaynak, and J.D. Spengler, Ozone decay rates in residences, J. Air Waste Manag. Assoc. 49, 1238-1244 (1999).

[8] E. Uhde and T. Salthammer, Impact of reaction products from building materials and furnishings on indoor air quality - A review of recent advances in indoor chemistry, Atmos. Environ. 41(15), 3111-3128 (2007).

[9] R.S. Hayes, Use of an indoor air quality model (IAQM) to estimate indoor ozone levels, J. Air Waste Manag. Assoc. 41(2), 161-170 (1991).

[10] T. Grøntoft, Dry deposition of ozone on buildings materials. Chamber measurements and modeling of the time dependent deposition, Atmos. Environ. 36, 56615670 (2002).

[11] C.J. Weschler and H.C. Shields, Potential reactions among indoor pollutants, Atmos. Environ. 31(21), 3487-3495 (1997).

[12] L.E. Sparks, IAQ Model for Windows RISK Version 1.0 User Manual, EPA-600/R-96-037 (NTIS PB96501929) (Office of Research and Development, Research Triangle Park, USA, 1996).

[13] B.A. Tichenor, Z. Guo, L.E. Sparks, and M.A. Mason, The interaction of vapor phase organic compounds with indoor sinks, Indoor Air 1, 23-35 (1991).

[14] V. Valuntaite, The Investigation and Assessment of the Man-made Ozone Formation and Dispersion, $\mathrm{PhD}$ thesis (Technika, Vilnius, 2009) 151 p.

\title{
OZONO KONCENTRACIJOS PATALPOSE MODELIAVIMAS
}

\author{
S. Byčenkienéa $\dot{a}^{\mathrm{a}}$ V. Valuntaité ${ }^{\mathrm{b}}, \mathrm{R}$. Girgždiené $\dot{\mathrm{a}}^{\mathrm{a}, \mathrm{b}}$ \\ ${ }^{a}$ Fizikos institutas, Vilnius, Lietuva \\ ${ }^{\mathrm{b}}$ Vilniaus Gedimino technikos universitetas, Vilnius, Lietuva
}

\begin{abstract}
Santrauka
Nagrinėjami ozono koncentracijos pasiskirstymo skaitinio modeliavimo ir eksperimentiniai duomenys, gauti generuojant ozona patalpose esant skirtingoms ventiliacijos sąlygoms. Ozono koncentracijoms patalpose ivvertinti pritaikytas RISK modelio algoritmas, atsižvelgiant i kambarių parametrus, ozono nusėdimo ant pa-
\end{abstract}

klotinių paviršių greičius bei oro srautus. Eksperimentinių ir modeliavimo duomenu palyginimas parodè, kad ozono koncentracija patalpose labiausiai veikè oro pasikeitimo tarp kambarių greitis ir paklotinių paviršių rūšys. Tiriant modelio tikslumą, skaitinio modeliavimo rezultatai palyginti su eksperimentiniais duomenimis (koreliacija $r=0,8$ ). 